\title{
The Negative Effect of Brand Attachment: How Attachment Styles Help Explain Anti-Brand Behavior
}

\author{
Yuan Yuan, Ming Lei \\ School of Business Administration, South China University of Technology, Guangzhou, China \\ Email: 1406944855@qq.com
}

How to cite this paper: Yuan, Y. and Lei, M. (2017) The Negative Effect of Brand Attachment: How Attachment Styles Help Explain Anti-Brand Behavior. Open Journal of Business and Management, 5, 141148.

http://dx.doi.org/10.4236/ojbm.2017.51013

Received: November 8, 2016

Accepted: January 2, 2017

Published: January 5, 2017

Copyright $\odot 2017$ by authors and Scientific Research Publishing Inc. This work is licensed under the Creative Commons Attribution International License (CC BY 4.0).

http://creativecommons.org/licenses/by/4.0/

\begin{abstract}
Enterprises tend to attach importance to consumer brand relationship in the marketing context, especially the establishment and culture of attachment relationship, and they try to maintain brand loyalty through consumers' high self-connection. But they ignore the possibility that brand attachment leads to anti-brand behavior; however, previous study was less involved in the negative effects of brand attachment and negative brand behavior. So on the basis of relevant research literature review, we firstly illustrate two kinds of incentive of anti-brand behavior: 1) the loss of functional benefit; 2) the violation of self-concept, and then discussed the theoretical framework that brand attachment leads to anti-brand behavior from the perspective of consumers' individual characteristics. The purpose of this paper is to explore the strong brand attachment relationship between consumers and brand when and why it will be transformed into a strong negative brand behavior, and thus provide a new perspective on the study of brand attachment.
\end{abstract}

\section{Keywords}

Brand Attachment, Attachment Style, Anti-Brand Behavior

\section{Introduction}

Gao Xiang (2012) argues that brand attachment has a positive impact on brand loyalty by influencing the relationship of brand [1], especially if the brand is vilified by negative information, customers will strive to safeguard the interests of the brands if they are threatened (Belk, 1998) [2]. Therefore, traditional views think that consumers who have higher level of attachment often won't focus too much on brand negative information, and they will explain the negative information based on earlier positive product evaluation, thus weakening the influence of negative information. However, strong brand attachment does not mean its absolute brand loyalty; accordingly, it should con- 
tain at least one kind of tipping point, such as the degree of damage, the individual differences of consumer, etc.

Grégoire and Fisher (2006) propose the notion of "love becomes hate"; they thought that consumers with high relationship quality always have higher expectations for the brand, then they are easier to feel betrayed by the brand and have higher desire of revenge [3]. Johnson (2011) indicates that the more self-relevant a consumer-brand relationship, the more likely the anti-brand retaliatory behaviors after the relationship ends, and self-conscious emotion motivates consume hostility and retaliation [4]. Hou Haiqing (2011) analyzes the bidirectional effects of customers' attachment to the brand on negative marketing events [5]. Park (2013) puts forward Attachment-aversion model of customer-brand relationships [6]. Japutra (2014) studies a conceptual framework of brand attachment's detrimental outcomes, and then he points that companies' opportunism activities and incongruity of values between consumer and brand will lead to anti-brand behavior [7]. However, so far, domestic and foreign scholars to explore negative role of brand attachment are still very limited.

Therefore, this paper will focus on the negative effects of brand attachment and the moderating effect of attachment style between brand attachment and anti-brand behavior. First of all, we discuss the inducing factors that brand attachment will lead to anti-brand behavior. Second, attachment style as reflecting characteristics of the consumer's individual difference factors is less involved in the marketing situation of related research, so we know very little about its influence mechanism.

\section{Theoretical Background}

\subsection{Concept for Anti-Brand Behavior}

Anti-brand behavior will cause many adverse effects to the brand, but there is no uniform definition. Some literature focuses on the behavior of consumers who have negative feelings, beliefs, and attitudes towards brands, such as brand hate, brand resistance, brand revenge, brand avoidance and anti-consumption behavior.

Hogg (1998) pointed out that the decision not to purchase a product can be caused by two aspects of negative choices: non-choice and anti-choice [8]. Anti-choice refers to abandonment, avoidance, and aversion, and non-choice refers to availability and accessibility constrained by affordability. Huefner and Hunt (2000) divide revenge behavior into six categories: cost/loss, vandalism, trashing, stealing, negative word of mouth and personal attack [9]. When consumers are wrongly treated by enterprise, brand avoidance and retaliation will emerge (Grégoire et al., 2009) [10]. Lee et al. (2011) think that anti-consumption does not necessarily mean that people would completely stop consuming certain products or services, as it also covers rejection, restriction, and reclamation of consumption [11].

Therefore, anti-brand behavior refers to that consumers reject even revenge certain brand. Besides stopping buying, negative word-of-mouth and turning to other competitor, it should also include the change of consumers' emotion and attitude. Although consumers can access to a particular brand and economically afford, but they will still retaliate against a brand deliberately because of some motivations. 


\subsection{Motives for Anti-Brand Behavior}

Ethnic hatred, national culture, social effect can influence consumers whether to boycott, while consumers are consistent in behavior, but they are not based on the same motivation to make anti-brand behavior. Therefore, relative to collective and organizational influence, this article mainly focuses on individual factors of consumers.

First of all, from the perspective of interests of consumers, the establishment of brand attachment is based on that brand meets consumers' interests and values of life. It is mainly reflects in functional value and individual enjoyment. If product harms a person's personal safety and health, and thus violates their trust in the brand technology reliability, consumers will experience the loss of emotional distress and psychological trauma (Lee et al., 2011) [11]. Consumers will form functional and aesthetic expectations about product or service in the process of consumption, if enterprises provide inferior products will lead to not meet expectations, it can cause consumer dissatisfaction. Funches et al. (2009) point out that failure of the product or service recovery will stimulate consumers to produce retaliation [12]. The essence of consumer-brand relationship is the exchange of value and interest. Product performance directly affects consumers' ability to solve problem, and it relates to the satisfaction of consumer selfefficacy [13]. If brand exposes defects in the functional properties and other important quality characteristics, consumers will think that the product function value is insufficient and it will shake the foundation of consumer-brand relationship (Xu Xiaolong et al., 2012) [14].

Secondly, from the perspective of consumers' self-concept, brand attachment contains important aspects of consumer self-concept and self-image, and it mainly reflects in social attributes of the product. If brand meaning deviates from individual's self-definition and emotional well-being, consumers will gradually lose for the brand's identity and belonging. When product image is not consistent with consumer, it will cause consumers to avoid, disgust and abandon the brand (Hogg et al., 2009) [15]. In order to improve and enrich themselves, consumers can also avoid those brands that can only realize actual self (Sirgy, 1982) [16]. In addition, it can also lead to moral avoidance when the specific value of the brand conflicts with the ideology of consumer beliefs, such as enterprise violates ethics and social responsibility (Lee et al., 2009) [17]. For example, consumers are increasingly concerned about environmental friendly products and against excessive consumption or non-recyclable garbage in the consumption of fast fashion brand (Kim, 2013) [18].

\section{The Moderating Effect of Attachment Style}

In the social/personality psychology, the concept of attachment style is a systematic model for expectation, demand, emotion and emotion regulation strategies. Attachment style difference is caused by the internal working model, and different attachment style reflects different personal experiences of human relationships. Attachment style contains two scale dimensions: anxiety and avoidance. Anxiety is the extent to which a consumer has excessive fears of rejection and abandonment, excessive worries and a need for approval; whereas, avoidance is the extent to which a consumer has excessive fears of depending on others. 
Revenge is closely related to negative emotion and is also a consequence of attributing failure to others (Grégoire et al., 2010) [19]. We posit that attachment style moderates the link between brand attachment and anti-brand behavior. For example, consumers who have high anxiety are more likely to take anti-brand behavior because of higher self-esteem and negative attribution, but secure consumers are opposite.

Thomson, Whelan and Johnson (2012) pointed out that the attachment style will lead to retaliation, including consumer self-image threat and interest losses will have mediating effect on this role [20]. Through reading the related literature about the attachment style, we find that different attachment styles have a great difference in cognition and judgment of threat factors, and the degree of perceived corporate betrayal is different, which is reflected in three aspects: attribution, trust and consumption emotion.

\subsection{Attachment Style and Attribution}

Attribution theory views people as rational information processors whose actions are influenced by their causal inferences. Different attachment mental models have different attribution to the behavior of self and others, and individuals of secure attachment are more tolerant to their partner's behavior than the individuals who are not secure attachment (Zuo Enling, 2009) [21]. Positive self-model can induce individuals to perceive relationship events in an adaptive way, while negative self-model will make the individual tend to attribute in a non-adaptive way through negative interpretation (Sumer et al., 2004) [22]. Compared with anxious-ambivalent individual, secure individual has less negative attribution on partner behavior (Collins, 1996) [23]. Whelan and Dawar (2014) argue that secure individual is less likely to be responsible, controlled and intentional attribution in ambiguous situations [24]. However, insecure attachment individual does not believe the goodwill of others and tend to blame undefined behavior or intention to others.

\subsection{Attachment Style and Trust}

Main aspects of trust includes the evaluation of others' behavior is a reliable and predictable, and believe that care individual needs (Mikulincer, 1998) [25]. High anxiety attachment individuals are afraid of rejection and are not sure if partners are available and responsive when they need them, so they tend to not trust others (Hazan et al., 1987) [26]. High avoidance attachment individuals desire to be independent of their partners and often experience a lower interpersonal trust. Therefore, secure attachment individuals think others are available and tend to believe attachment object. Insecure attachment individuals do not see relying on other people as a comfortable partner relationship and maintain a high degree of vigilance against threat factors.

\subsection{Attachment Style and Customers' Emotion}

When the relationship between consumer and brand is threatened, there are some differences between attachment styles in emotional reaction and behavior tendency. Secure individuals have a positive attitude towards brand, and it is easier for them to ignore negative information and behavior of the product or brand. Anxiety individuals 
have lower error tolerance. For example, they will show strong sadness and anger and even take extreme behavior to revenge a brand which betrayal them. Avoidant attachment consumers will keep distance from the source of pain on cognition and behavior (Mikulincer et al., 1998) [27]. Usually, secure attachment individual positively related to the functional angry and the anger focuses on the situation of rational analysis and solve the problem. However, insecure attachment individuals are often affected by cognitive bias and tend to punishment and harm the angry demagogue (Collins, 1996) [23].

In order to better understand when and how brand attachment may result in antibrand behaviour, we try to develop a conceptual model as shown in Figure 1. Scholars consider brand attachment a key requisite in consumer-brand relationships that create favourable consumer behaviours such as positive brand attitudes. Our framework reveals that the link between brand attachment and anti-brand behaviors is driven by attachment style which influences consumers' attribution, trust and emotion. In particular, with respect to the secure attachment style of consumers, anxious consumers are more likely to take extreme actions when they perceive the threat of negative behavior of enterprises, therefore, the attachment style has a moderate effect on the relationship. This article attempts to explore how brand attachment leads to anti-brand bebaviours. We posit that without strong attachment to the brand, it is unlikely that a consumer will elicit anti-brand behaviors. As shown in Figure 1, anti-brand behaviors occurs when consumers display strong bonding between the self and the brand.

\section{Discussion and Conclusion}

In the marketing context, not all consumers who have high attachment level will take initiative to resist the influence of the negative information, and it is influenced by consumer attachment style. This study puts forward a theoretical model that brand attachment may lead to anti-brand behavior, so as to provide a useful reference for the enterprise. Specifically, we try to explore how attachment style among consumers influences their negative emotion, how they attribute, and with what consequences.

By evaluating consumer's attachment style, enterprises can understand which consumers are more tolerant or which consumers are more stringent, and thus decide how

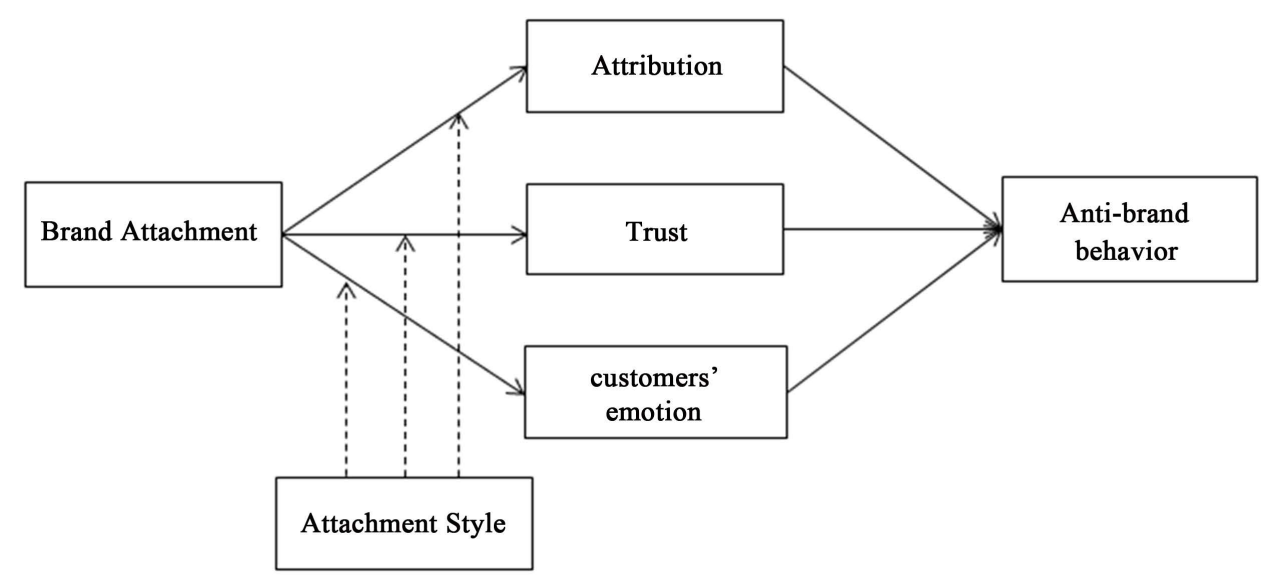

Figure 1. Conceptual model of the negative effect of brand attachment. 
to deal with this relationship. Marketers should pay more attention to the relationship and actively clarify the truth to maintain brand trust. Consumers have narrow channel and site to release their emotions and dissatisfactions, so it is important to establish a well-founded platform between enterprise and customers. Because lifestyle branding has gained popularity among companies, company should become a practitioner of social responsibility movement to maintain reliable relation with consumers.

Although the establishment of brand attachment has positive impact on attribution, brand beliefs and emotional expression, this relationship is regulated by consumer's characteristics, especially the consumer attachment style. Compared with secure attachment style, fearful attachment consumers are more likely to take anti-brand behavior to end its relationship with the brand. It is hard to establish close relationship with avoidant attachment consumers. But once they set up relationship with brand, they think themselves to have already invested more resources. If the brand betrays their trust, this type of consumers is likely to take anti-brand behavior. Therefore, the establishment of attachment can produce positive effect, but if marketers do not take this relationship seriously, it can also become a booster for the breakdown of close relationships.

\section{Future Research}

The research on the relationship between brand attachment and anti-brand behavior has great practical significance. Future scholars may try to pay more attention to the negative influence of brand attachment and the boundary conditions of this negative effect, so as to enhance the favorable influence of brand attachment and avoid its negative effects to enterprises. Attachment style as a reflection of consumers' own characteristics, and we can pay more attention to its influence in the study of consumer behavior. Relative to secure attachment, anxious customers may be more sensitive to relational cues and tend to overreact to critical incidents. Understanding customer attachment style can help with new customer acquisition, so it is an important construct that should be seriously considered in future research.

This paper puts forward the research model based on theoretical research, but still lacks relevant empirical research. These problems can be further explored in the future.

\section{References}

[1] Gao, X. (2012) Study on the Influence of Consumer Brand Attachment on Brand Loyalty. Huaqiao University, Quanzhou.

[2] Belk, R.W. (1988) Possessions and the Extended Self. Journal of Consumer Research, 15, 139-168. https://doi.org/10.1086/209154

[3] Gregoire, Y. and Fisher, R.J. (2006) The Effects of Relationship Quality on Customer Retaliation. Marketing Letters, 17, 31-46. https://doi.org/10.1007/s11002-006-3796-4

[4] Johnsou, A.R., Matear, M. and Thomoson, M. (2011) A Coal in the Heart: Self-Relevance as a Post-Exit Predictor of Consumer Anti-Brand Actions. Journal of Consumer Research, 38, 108-125. https://doi.org/10.1086/657924

[5] Hou, H.Q. (2011) A Two-Way Role of Brand Attachment from the Perspective of “TOYOTA Recall”. Journal of Xi an Petroleum University (SOCIAL SCIENCE EDITION), No. $1,48-51$. 
[6] Park, C.W., Eisingerich, A.B. and Park, J.W. (2013) Attachment-Aversion (AA) Model of Customer-Brand Relationships. Journal of Consumer Psychology, 23, 229-248. https://doi.org/10.1016/j.jcps.2013.01.002

[7] Japutra, A., Ekinci, Y., Simkin, L., et al. (2014) The Dark Side of Brand Attachment: A Conceptual Framework of Brand Attachment's Detrimental Outcomes. The Marketing Review, 14, 245-264. https://doi.org/10.1362/146934714X14024779061875

[8] Hogg, M.K. (1998) Anti-Constellations: Exploring the Impact of Negation on Consumption. Journal of Marketing Management, 14, 133-158. https://doi.org/10.1362/026725798784959354

[9] Huefner, J. and Hunt, H.K. (2000) Consumer Retaliation as a Response to Dissatisfaction. Journal of Consumer Satisfaction, Dissatisfaction \& Complaining Behavior, 13, 61-82.

[10] Gregoire, Y., Tripp, T.M. and Legoux, R. (2009) When Customer Love Turns into Lasting Hate: The Effects of Relationship Strength and Time on Customer Revenge and Avoidance. Journal of Marketing, 73, 18-32. https://doi.org/10.1509/jmkg.73.6.18

[11] Lee, M.S.W., Roux, D., Cherrier, H. and Cova, B. (2011) Anti-Consumption and Consumer Resistance: Concepts, Concerns, Conflicts, and Convergence. European Journal of Marketing, 45, 1680-1687. https://doi.org/10.1108/ejm.2011.00745kaa.001

[12] Funches, V., Markley, M. and Davis, L. (2009) Reprisal, Retribution and Requital: Investigating Customer Retaliation. Journal of Business Research, 62, 231-238. https://doi.org/10.1016/j.jbusres.2008.01.030

[13] Ainsworth, M.D.S., Blehar, M., Waters, E. and Wall, S. (1978) Patterns of Attachment: A Psychological Study of the Strange Situation. Erlbaum, Hillsdale.

[14] Xu, X.L. and Su, Y. (2012) Research on the Relationship between Consumers and Brands in the Product Harm Crisis. Journal of Zhongnan University of Economics and Law, 43-49.

[15] Hogg, M.K., Banister, E.N. and Stephenson, C.A. (2009) Mapping Symbolic (Anti-) Consumption. Journal of Business Research, 62, 148-159. https://doi.org/10.1016/j.jbusres.2008.01.022

[16] Sirgy, M.J. (1982) Self-Concept in Consumer Behavior: A Critical Review. Journal of Consumer Research, 9, 287-300. https://doi.org/10.1086/208924

[17] Lee, M.S.W., Motion, J. and Conroy, D. (2009) Anti-Consumption and Brand Avoidance. Journal of Business Research, 62, 169-180. https://doi.org/10.1016/j.jbusres.2008.01.024

[18] Kim, H. (2013) The Motivational Drivers of Fast Fashion Avoidance. Journal of Fashion Marketing and Management, 17, 243-260. https://doi.org/10.1108/JFMM-10-2011-0070

[19] Gregoire, Y., Laufer, D. and Tripp, T.M. (2010) A Comprehensive Model of Customer Direct and Indirect Revenge Understanding the Effects of Perceived Greed and Customer Power. Journal of the Academy of Marketing Science, 38, 738-758. https://doi.org/10.1007/s11747-009-0186-5

[20] Thomson, M., Whelan, J. and Johnson, A.R. (2012) Why Brands Should Fear Fearful Consumers: How Attachment Style Predicts Retaliation. Journal of Consumer Psychology, 22, 289-298. https://doi.org/10.1016/j.jcps.2011.04.006

[21] Zuo, E.L. (2000) The Relationship between Adult Attachment, Attribution Style and Interpersonal Trust of College Students. Northeast Normal University, Changchun.

[22] Sumer, N. and Cozzarelli, C. (2004) The Impact of Adult Attachment on Partner and SelfAttributions and Relationship Quality. Personal relationships, 11, 355-371. https://doi.org/10.1111/j.1475-6811.2004.00087.x

[23] Collins, N.L. (1996) Working Models of Attachment: Implications for Explanation, Emotion, and Behavior. Journal of Personality and Social Psychology, 71, 810-932. https://doi.org/10.1037/0022-3514.71.4.810 
[24] Whelan, J. and Dawar, N. (2014) Attributions of Blame Following a Product-Harm Crisis Depend on Consumers' Attachment Styles. Marketing Letters, 27, 285-294. https://doi.org/10.1007/s11002-014-9340-Z

[25] Mikulincer, M. (1998) Attachment Working Models and the Sense of Trust: An Exploration of Interaction Goals and Affect Regulation. Journal of Personality and Social Psychology, 74, 1209-1224. https://doi.org/10.1037/0022-3514.74.5.1209

[26] Hazan, C. and Shaver, P. (1987) Romantic Love Conceptualized as an Attachment Process. Journal of Personality and Social Psychology, 52, 511-524. https://doi.org/10.1037/0022-3514.52.3.511

[27] Mikulincer, M. (1998) Adult Attachment Style and Individual Differences in Functional versus Dysfunctional Experiences of Anger. Journal of Personality and Social Psychology, 74, 513-524. https://doi.org/10.1037/0022-3514.74.2.513

Submit or recommend next manuscript to SCIRP and we will provide best service for you:

Accepting pre-submission inquiries through Email, Facebook, LinkedIn, Twitter, etc. A wide selection of journals (inclusive of 9 subjects, more than 200 journals)

Providing 24-hour high-quality service

User-friendly online submission system

Fair and swift peer-review system

Efficient typesetting and proofreading procedure

Display of the result of downloads and visits, as well as the number of cited articles

Maximum dissemination of your research work

Submit your manuscript at: http://papersubmission.scirp.org/

Or contact ojbm@scirp.org 